\title{
PAROTID GLAND TUMORS: AN EVALUATION AT TERTIARY CARE HOSPITAL.
}

\footnotetext{
1. MBBS, MS (General Surgery) Associate Professor LUMHS, Jamshoro.

2. BDS

Lecturer Institute of Dentistry, LUMHS, Jamshoro.

3. BDS, MSc

Lecturer

Department of Oral \& Maxillofacia Surgery LUMHS.

4. BDS, MSc (OMFS)

Lecturer

Department of Oral \& Maxillofacia Surgery

LUMHS.
}

Correspondence Address:

Dr. Salman Shams

Department of Oral \& Maxillofacial Surgery

LUMHS

salman_omfs@hotmail.com

Article received on:

28/02/2019

Accepted for publication:

17/05/2019

\begin{abstract}
Agha Taj Mohammed', Sajda Khuhawar ${ }^{2}$, Bibi Gulsama ${ }^{3}$, Salman Shams ${ }^{4}$
ABSTRACT... Objectives: To evaluate epidemiological pattern, early diagnostic tool and histological type of parotid gland tumors. Study Design: Prospective cross sectional study. Setting: Department of Oral \& Maxillofacial Surgery \& General Surgery Liaquat University hospital Hyderabad. Period: From 2013 to 2017. Material \& Methods: Study contains 67 patients of parotid tumors after initial diagnosis. These patients were first diagnosed by FNAC (Fine needle aspiration cytology) along with CT scan \& MRI where required. Final diagnosis was established after histopathological diagnosis of tumor. Results: Males were predominantly involved in both tumor patterns. Most common age group was $5^{\text {th }}$ decade in both benign and malignant tumors. FNAC has diagnostic sensitivity of almost $90-97 \%$. Out of 67,51 tumors were benign and 16 were malignant. Pleomorphic adenoma was the most common benign tumor while mucoepidermoid carcinoma was found as most received malignant tumor. Conclusion: Pleomorphic adenoma is most commonly found benign tumor and mucoepidermoid carcinoma is found more in numbers as malignant tumor.
\end{abstract}

Key words: Benign, Malignant, Mucoepidermoid Carcinoma, Pleomorphic Adenoma, Parotid, Tumor.

Article Citation: Mohammed AT, Khuhawar S, Gulsama B, Shams S. Parotid gland tumors: an evaluation at Tertiary Care Hospital. Professional Med J 2020; 27(1):8083. DOI: 10.29309/TPMJ/2020.27.1.3324

\section{INTRODUCTION}

Tumors of salivary gland represent an essential area in the field of maxillofacial surgery and pathology but are infrequent, comprising of $3 \%$ of all head and neck tumors and $0.6 \%$ of all neoplasms of the body. ${ }^{1,2,3}$ Parotid gland has high ratio of occurrence of salivary tumors that is about 70 to $80 \%$, followed by submandibular gland, sublingual gland, and minor salivary gland, these tumors are also widely distributed in adults and childrens. ${ }^{4}$

The parotid gland is affected in a good number often, ranging from $36.6 \%$ to $83 \% .^{3}$ Malignant tumors are underground, taking place in 15-32\% of cases. ${ }^{5}$ The most familiar malignant and benign tumors are the mucoepidermoid carcinoma and the pleomorphic adenoma respectively. ${ }^{6}$

The recent journalism roughly guesses that $80 \%$ of these lumps are benign, with pleomorphic adenoma being the most widespread and involves parotid gland most frequently. ${ }^{4}$ It come about between the fourth and sixth decades of life, some have encountered between $3^{\text {rd }}$ to $5^{\text {th }}$ aswel. ${ }^{7}$ From clinical point of view the most common expression of pleomorphic adenoma is the presence of a solitary, hard, firm, lobulated, movable nodular lesion with well clear borders that is unproblematic to palpation and of extended progression. This category of tumor can be pretty huge and consistently spares the job of the facial musculature.

Mucoepidrmoid carcinoma primary reported by Massao and Berger in 1942 as a separate pathologic unit and is labeled as the frequently occurring malignancy of salivary gland, that typically shows the involvement of parotid, subamandibular, sublingual and minor salivary glands. ${ }^{8}$ In this vicinity the second most common malignancy seen is cystic adenoid carcinoma. Rare occurrence of parotid tumors is seen in the form of carcinoma of ex pleomorphic adenoma, 
adenocarcinoma and acinar cell carcinoma. ${ }^{9}$

The main purpose of this study was to recognize that which pattern of parotid tumors are more common in this part of country and also to see the diagnostic accuracy of fine needle aspiration technique in the diseases of parotid gland. Definitive diagnosis is usually not done by FNA but it has the role to differentiate benign from malignant tumors.

\section{MATERIAL \&METHODS}

This prospective cross sectional study with non probability purposive sampling technique is a combine work between maxillofacial surgery and general surgery department of liaquat university hospital Hyderabad.

All the data was recorded on predesigned proforma. Patients included were either gender, irrespective of age, with parotid region swelling or mass. All the patients with parotid gland mass were first assessed clinically and radiographically. Initial diagnosis was made on the basis of fine needle aspiration cytology with collaboration of pathology department. Final diagnosis was confirmed with histological confirmation (incisional or excisional biopsy). CT \& MRI were carried out wherever required. Patients who were not willing for participation and those who were mentally retarded were set in exclusion criteria.

\section{RESULTS}

Figure-1 shows gender distribution:

There were 49 male and 18 females patients which shows male predominance.

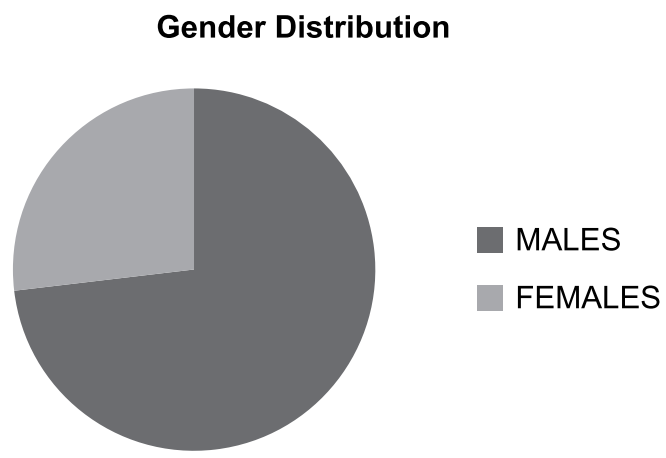

Figure-1.
Most common age group involved was fifth decade of life as shown in Table-I.

\begin{tabular}{|l|c|c|}
\hline \multicolumn{1}{|c|}{ Age Group } & No of Patients & $\%$ \\
\hline 11 to 20 years & 01 & 1.49 \\
\hline 21- 30 years & 02 & 2.98 \\
\hline 31 to 40 years & 11 & 16.41 \\
\hline 41 to 50 years & 39 & 58.2 \\
\hline 51 to 60 years & 14 & 20.8 \\
\hline TOTAL & 67 & $100 \%$ \\
\hline
\end{tabular}

Table-I. Showing details about age groups affected.

Figure-2 shows nature of tumor pattern:

51 patients reported with benign and 16 with malignant tumors

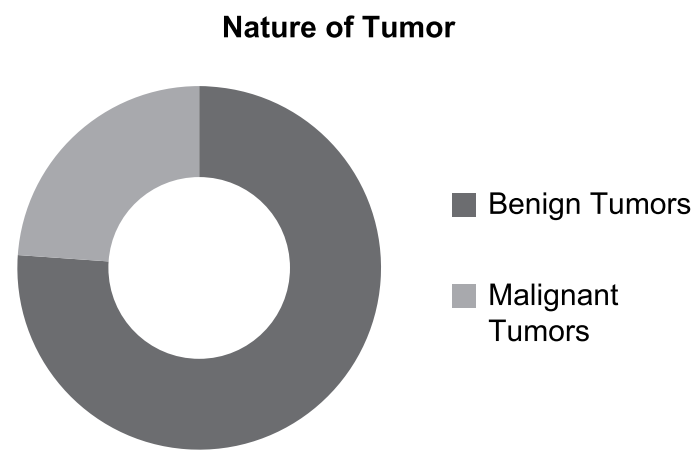

Figure-2.

Table-III\&IV shows nature of tumor along with histological type diagnosed.

\begin{tabular}{|l|c|c|}
\hline \multicolumn{1}{|c|}{ Histological Type } & No of Patients & $\%$ \\
\hline Pleomorphic Adenoma & 44 & 86.27 \\
\hline Warthin Tumor & 02 & 3.92 \\
\hline Lipoma & 04 & 7.84 \\
\hline Schwannoma & 01 & 1.96 \\
\hline TOTAL & 51 & $100 \%$ \\
\hline
\end{tabular}

Table-II. Benign tumors.

\begin{tabular}{|l|c|c|}
\hline \multicolumn{1}{|c|}{ Histological Type } & No of Patients & $\%$ \\
\hline Mucoepidermoid Carcinoma & 11 & 68.75 \\
\hline Adenoid Cystic Carcinoma & 02 & 12.5 \\
\hline $\begin{array}{l}\text { Carcinoma of } \\
\text { Ex-Pleomorphic Adenoma }\end{array}$ & 02 & 12.5 \\
\hline Fibrosarcoma & 01 & 6.25 \\
\hline Total & 16 & $100 \%$ \\
\hline
\end{tabular}

Table-III. Malignant tumors 


\begin{tabular}{|l|c|c|}
\hline Tumor Type & FNAC Result & Histology Result \\
\hline Benign & 54 Patients & 51 Patients \\
\hline Malignant & 13 Patients & 16 Patients \\
\hline \multicolumn{2}{|c|}{ Table-IV. Shows result of FNAC and histological } \\
report
\end{tabular}

\section{DISCUSSION}

The pathology of the salivary glands focuses on that of the parotid gland. ${ }^{10}$ In this study males are predominantly affected as compared to females in both type of tumors i.e about $73 \%$. But the results in other parts of world shows different results like the study carried out by ES Diom ${ }^{11}$ shows females predominance where $61 \%$ cases occurred in females, another study of Maahs GS ${ }^{10}$ also shows majority of patients as females.

The commonness of salivary gland tumors peaks in the sixth and seventh decades of life. Satko et $\mathrm{al}^{12}$ reported a mean age of 53 years (ranging from 2 to 87 years). This current study shows majority of patients in fifth decade of life i.e age range of 41 to 50years, which is in support of data showed by Maahs GS. ${ }^{10}$ Here again the results of different parts of world are in contrast to this study, like study of Jude $\mathrm{UO}^{13}$ shows most of the patients in $3^{\text {rd }}$ and $6^{\text {th }}$ decade of life.

Benign tumors are most frequently found with parotid tumors as compared to malignant tumors. This study also shows high occurrence of benign as compared to malignant tumors. This resembles the literature from other parts of world. ${ }^{14,15}$

Pleomorphic adenoma is most commonly encountered benign tumors in this study and mucoepidermoid carcinoma is frequently seen malignant entity. Masanja ${ }^{16}$ and Vuhahula ${ }^{17}$ found same results as shown by our study where he found pleomorphic adenoma as most commonly found tumor.

Investigative sensitivity of $100 \%$ has been seen with FNAC, while diagnostic specificity of $80 \%$, positive predictive value of $97.0 \%$, negative predictive value of $100 \%$ and accurateness of $97.3 \%$ for diagnosing benign parotid tumors. ${ }^{18}$ We also found the same results with FNAC like the several studies have declared.

\section{CONCLUSION}

The profile of parotid tumor is rich and complex, as are the cell populations of the gland itself. It was concluded that benign tumors more frequently occur in parotid tumors as compared to malignant ones. Pleomorphic adenoma is most commonly found benign tumor and mucoepidermoid carcinoma is found more in numbers as malignant tumor.

Copyright $\odot 17$ May, 2019.

\section{REFERENCES}

1. Lee DH, Yoon TM, Lee JK. Clinical analysis of parotid tumors in patients over 60-year-old: A retrospective study of 78 cases. Int Jr Geront. 2017; 11:114-117.

2. Lee YM, Choi HJ, Kim JW, et al. Parotid gland tumors in a Korean population. J Craniofac Surg. 2012; 23:205209.

3. Sardar MA, Ganvir S M, Hazarey V K. A demographic study of salivary gland tumors. SRM J Res Dent Sci 2018; 9:67-73.

4. Carlson ER et al. Malignant salivary gland tumors. J Oral Maxillofac surg 2016; 74(11):2340-41.

5. Satko I, Stanko P, Longauerova I. Salivary gland tumors treated in the stomatological clinics in Bratislava. $J$ Cranio maxillofac Surg. 2000; 28:56-61.

6. Bittar RF, Ferraro HP, et al. Facial paralysis after superficial parotidectomy: Analysis of possible predictors of this complication. Braz $\mathrm{J}$ Otorhinolaryngol. 2016; 82(4):447-451.

7. Foresta E, Torroni A, Di Nardo F, De Waure C, Poscia $A$, Gasparini G, et al. Pleomorphic adenoma and benign parotid tumors: Extracapsular dissection vs superficial parotidectomy -review of literature and meta-analysis. Oral Surg Oral Med Oral Pathol Oral Radiol. 2014; 117:663-762.

8. Jain S, Hassan S, Vyas N, Shah N. Pleomorphic adenoma of the parotid gland: Report of a case with review of literature. Ethiop J Health Sci. 2015 Apr; 25(2): 189-194.

9. Jarde SJ, Das S, Babu C, et al. Mucoepidermoid carcinoma of the palate: A rare case report. J Indian Soc Periodontol. 2016 Mar-Apr; 20(2): 203-206. 
10. Maahs GS, Oppermann PO, Maahs LGP, Machado Filho $\mathrm{G}$, Ronchi AD. Parotid gland tumors: A retrospective study of 154 patients. Braz J Otorhinolaryngol. 2015; 81:301-6.

11. E-S. Diom et al. European Annals of Otorhinolaryngology, Head and Neck diseases 132 (2015) 9-12.

12. Satko I, Stanko P, Longauerova I. Salivary gland tumours treated in the stomatological clinics in Bratislava. J Craniomaxillofac Surg. 2000; 28:56-61.

13. Jude UO, Olu-Eddo AN. Salivary gland tumors, a twenty-year retrospective study. Afr J Med Health Sci 2014; 13:24-9.

14. Subhashraj K. Salivary gland tumors: A single institution experience in India. $\mathrm{Br} J$ Oral Maxillofac Surg 2008; 46(8):635-8.
15. Hernando M, Martín-Fragueiro L, Eisenberg G, et al. Surgical management of salivary gland tumours. Acta Otorrinolaringol Esp 2009; 60(5):340-5.

16. Masanja M, Kalyanyama B, Simon E. Salivary gland tumours in Tanzania. East African medical journal. 2003 Aug; 80(8):429-34.

17. Vuhahula E. Salivary gland tumors in Uganda: Clinical pathological study. African health sciences. 2004 Apr; 4(1):15-23.

18. Shah SA, Riaz U, Zubair M, et al. Surgical presentation and outcome of parotid gland tumors. J Coll Phys Surg Pak. 2013; 23:625-628.

\begin{tabular}{|c|c|c|c|}
\hline \multicolumn{4}{|c|}{ AUTHORSHIP AND CONTRIBUTION DECLARATION } \\
\hline Sr. \# & Author(s) Full Name & Contribution to the paper & Author(s) Signature \\
\hline 1 & $\begin{array}{l}\text { Agha Taj Mohammed } \\
\text { Sajda Khuhawar }\end{array}$ & $\begin{array}{l}\text { Principal author, Data } \\
\text { collection. } \\
\text { Results, Discussion. }\end{array}$ & \\
\hline 3 & Bibi Gulsama & Data collection. & \\
\hline 4 & Salman Shams & $\begin{array}{l}\text { Manuscript Designing, } \\
\text { References. }\end{array}$ & \\
\hline
\end{tabular}

